\title{
PEMANFAATAN LAHAN SELA PADA BUDIDAYA JERUK SISTEM TANAM RAPAT DI BANYUWANGI
}

\author{
Lyli Mufidah, Emi Budiyati, Sutopo \\ Balai Penelitian Tanaman Jeruk dan Buah Subtopika, \\ Jl.Raya Tlekung No.1 Junrejo, Batu \\ E-mail: lyli.mufidah@gmail.com,
}

\begin{abstract}
The high deficit in the trade balance value for citrus commodities can be an indication of the need for improvements in production and especially on the quality of citrus in Indonesia. Citrus cultivation with high density cropping system (SITARA) can be one of the strategies to increase production without increasing the area of planting land. The additions of intercropping in this system can be a solution for farmers' income, when citrus plants have not yet produced. Therefore, this study was aimed to analyze the costs and benefits of intercropping cultivation done between SITARA citrus plants with three cropping patterns (geometry) and intercropping plants which stated into four packages: (1) $4 \times 4$ (double) with chili intercropping, (2) $4 \times 4$ (double) variations (watermelon, tomatoes, broccoli, mustard greens: (3) $3 \times 4$ (double) with chili, (4) $3 \times 4$ (double) soybean. The results of the analysis showed that the $4 \times 4 \mathrm{~m}$ cropping pattern intercroped with watermelon, tomatoes, broccoli and green mustard provide the highest profit of Rp. 13,677,396 per 0.25 ha per year. Although the total $R / C$ ratio is still smaller than chili, but with variations the price decline in one commodity can be supported by other commodities. This pattern turns out to be the one that provide better citrus growth than the other four patterns, which can be seen from the rootstock and scion diameter also the average plant height that is 52, 43 dan $228 \mathrm{~cm}$, respectively. This can ben an indication that intercropping can be done without harming the main crop, if it gets the right treatment. To support the results, the interaction of trees (in this case citrus), soil, and seasonal crops can be evaluate more deeply.
\end{abstract}

Keywords: Farming analysis, Intercropping, High density cropping system, Citrus

\section{PENDAHULUAN}

Jeruk menempati urutan ketiga (setelah pisang dan rambutan) sebagai buah yang paling banyak dikonsumsi masyarakat Indonesia pada tahun 2015 dan 2016, dengan tingkat konsumsi 3,28 kg/kapita/tahun pada 2015 yang naik menjadi 3,60/kg/kapita/tahun pada 2016 (BPS 2017). Di sisi neraca perdagangan defisit masih terjadi baik dari sisi volume 86 ribu ton maupun nilai sebesar US\$ 117 juta rata-rata per tahun, pada kurun waktu yang sama (BPS 2018). Hal ini dapat menjadi indikasi perlunya perbaikan pada produksi dan terutama kualitas jeruk di Indonesia.

Di sisi lain, produk hortikultura, baik buahbuahan maupun sayuran memiliki rasio kontribusi produk domestik bruto (PDB) dengan penggunaan lahan paling efisien, dengan nilai 2,33 diikuti tanaman pangan (0,23), dan tanaman perkebunan sebesar 0,09 pada tahun 2012 (Gambar 1.). Hal ini menunjukkan bahwa jika dikelola dengan baik, maka per luasan lahan tanaman hortikultura dapat memberikan keuntungan yang menjanjikan dibandingkan tanaman pangan 
dan perkebunan. Dimana di Indonesia penguasaan lahan petani relatif kecil (kurang dari satu hektar).

Budidaya jeruk dengan sistem tanam rapat (SITARA) dapat menjadi salah satu strategi untuk peningkatan produksi tanpa menambah luasan lahan pertanaman (Gambar 2). Pada beberapa negara eksportir jeruk seperti China (Aubert 1990), Jepang (Tachibana \& Nakai 1989), dan Amerika (Ford et al. 1989) pendekatan ini telah diterapkan. Budidaya jeruk populasi tinggi dapat memberikan keuntungan ekonomi lebih awal dari produktivitas persatuan luas yang lebih tinggi meskipun produksi per pohon dewasa lebih rendah dibandingkan populasi normal. Di samping itu pendekatan ini mengefisienkan penggunaan tenaga kerja dan input produksi.

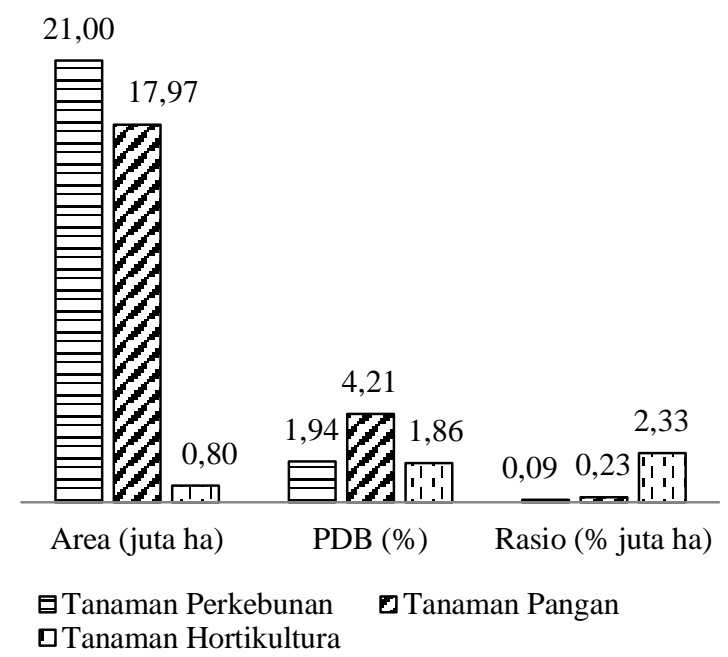

Gambar 1. Area Produksi (juta ha), Kontribusi PDB (\%) dan Rasio Kontibusi GDP terhadap Penggunaan Lahan, 2012 (Sumber: Pusat Data dan Sistem Informasi Pertanian 2013).

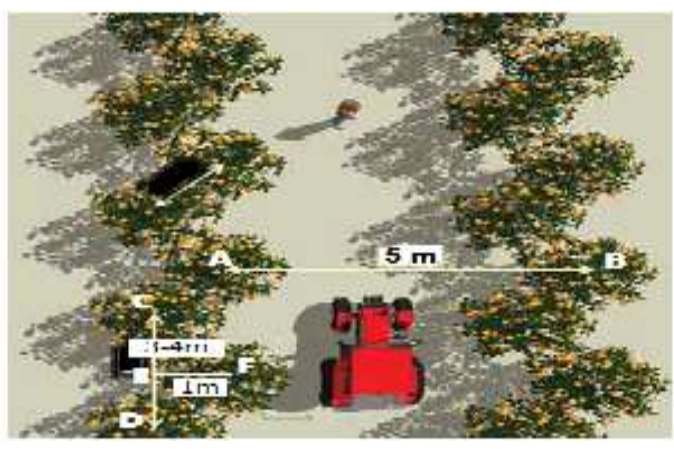

Gambar 2. Pola Penanaman Jeruk (Ganda).

Tanaman jeruk merupakan tanaman tahunan yang belajar berbuah pada usia tiga tahun. Selama belum berproduksi, petani tidak menghasilkan penerimaan, sehingga menghadapi kesulitan memenuhi kebutuhan rumah tangga. Dalam proses belum berproduksi, lahan sela dapat dimanfaatkan untuk tumpang sari dengan persyaratan tidak di bawah tajuk dan tidak menaungi. Tumpangsari pada tanaman jeruk menjadi perhatian dan perlu untuk dikelola agar hasil yang didapatkan setiap meter persegi dan setiap musim dapat maksimal (Rehman et al. 2014). Untuk mengkaji sumbangan penerimaan yang bisa diberikan oleh tanaman sela, maka perlu dilakukan analisa usaha tani pada tanaman tumpangsari yang dilakukan di sela tanaman jeruk SITARA dengan dua pola tanam (geometri). Jenis tanaman tumpangsari yang bisa ditanam berikut pola tanam antara lain: (1) $4 \times 4 \mathrm{~m}$ (ganda) dengan tanaman tumpangsari cabai; (2) 4x4 m (ganda) dengan variasi (semangka, tomat, brokoli, sawi); (3) $3 \times 4 \mathrm{~m}$ (ganda) dengan cabai; (4) $4 \times 4 \mathrm{~m}$ (ganda) kedelai.

Berbagai penelitian tentang budidaya tanaman semusim di antara tanaman tahunan 
yang belum menghasilkan telah dilakukan. Salah satu diantaranya adalah penelitian Srivastava et al. (2007) yang mengungkapkan bahwa jeruk yang ditumpangsarikan dengan kedelai dan buncis memiliki produktivitas yang lebih tinggi dibandingkan jeruk monokultur. Penelitian Ahmed, Khan, and Qasam (2013) yang menggunakan tanaman kedelai sebagai tumpangsari ternyata dapat mengurangi hama penggulung daun. Dari sisi ekonomi penelitian tentang tumpangsari di antara tanaman tahunan juga telah dilakukan, yakni Nchanji et al. (2016) mengungkapkan bahwa budidaya tumpangsari (ubi jalar, ubi kayu) pada kelapa sawit tidak hanya mengurangi biaya penyiangan, namun juga dapat menyediakan makanan dan penerimaan bagi petani selama masa menunggu kelapa sawit berproduksi. Hal yang selama ini dikhawatirkan bahwa tanaman tumpangsari dapat menurunkan produksi kelapa sawit ternyata tidak terbukti. Bahkan tumpangsari ini dapat menjadi wacana bagi penelitian lebih lanjut terkait pilihan tanaman yang sesuai. Hasil kajian Mursidah (2007) melaporkan bahwa terdapat perbedaan penerimaan dari pola tumpangsari yang digunakan yaitu karetpisang kepok dengan karet-nanas. Di sini juga diungkapkan bahwa keberadaan tanaman tumpangsari tidak mengganggu pertumbuhan tanaman karet, justru menjadikannya lebih baik. Selain itu hasil penelitian Guo et al. (2006) menyimpulkan bahwa pada kondisi sosial-ekonomi saat itu, lahan yang ditanami secara monokultur untuk karet dan teh memiliki nilai perkiraan lahan (LEV) yang lebih rendah dibandingkan lahan yang ditanami Karet dengan tumpangsari teh di dalamnya. Di samping itu, terdapat penelitian terkait yang menggunakan manajemen nutrisi untuk memperbaiki lahan yang sebelumnya digunakan untuk tumpangsari antara gandumkapas dan gandum-jagung di mana tanaman menunjukkan gejala defisiensi nutrisi khususnya nutrisi mikro (Yaseen \& Ahmad 2010).

Berbeda dengan penelitian-penelitian sebelumnya, penelitian ini menggunakan metode analisa usaha tani dari empat paket tanam tumpangsari pada budidaya jeruk tanam rapat yang bertujuan untuk memperoleh kombinasi antara tanaman pokok jeruk dengan tanaman sela yang memberikan penerimaan terbaik, tanpa mengganggu tanaman pokok, serta memberikan rujukan bagi petani yang menerapkan budidaya tanaman jeruk dengan sistem tanam rapat sebagai pilihan tanaman yang sesuai dan memberikan pengembalian yang lebih tinggi.

\section{METODE PENELITIAN}

\section{Kerangka Pemikiran}

Produksi jeruk per luasan lahan di Indonesia, sebagian besar masih belum maksimal. Hal ini diharapkan dapat diatasi dengan penerapan pola SITARA. Namun, sistem ini juga masih belum bisa menjawab permasalahan terkait pendapatan petani di masa menunggu tanaman berproduksi. Pada 
masa menunggu petani belum memperoleh penerimaan, sedangkan biaya untuk perawatan tetap berjalan dan petani tidak bisa memenuhi kebutuhan sehari-hari. Tumpangsari jeruk dengan tanaman semusim dapat menjadi alternatif pemasukan. Penggabungan kedua metode ini diharapkan dapat memberikan hasil yang maksimal bagi petani (Stuchi \& Girardi 2010) baik dari sisi produksi jeruk maupun dari penyediaan dana selama masa menunggu. Usahatani memberi gambaran pengalokasian sumber daya yang dibutuhkan secara efektif dan efisien untuk memperoleh keuntungan yang tinggi pada waktu tertentu (Soekartawi, 1995). Pengkombinasian dan pemilihan faktor produksi, baik tenaga kerja, tanah, serta sarana dan prasarana produksi dapat memberikan penerimaan selama masa menunggu tanaman utama menghasilkan (Daniel, 2002). Secara skematis alur pikir penerapan pola tanam rapat pada jeruk disertai tumpangsari tanaman semusim disajikan pada Gambar 3.

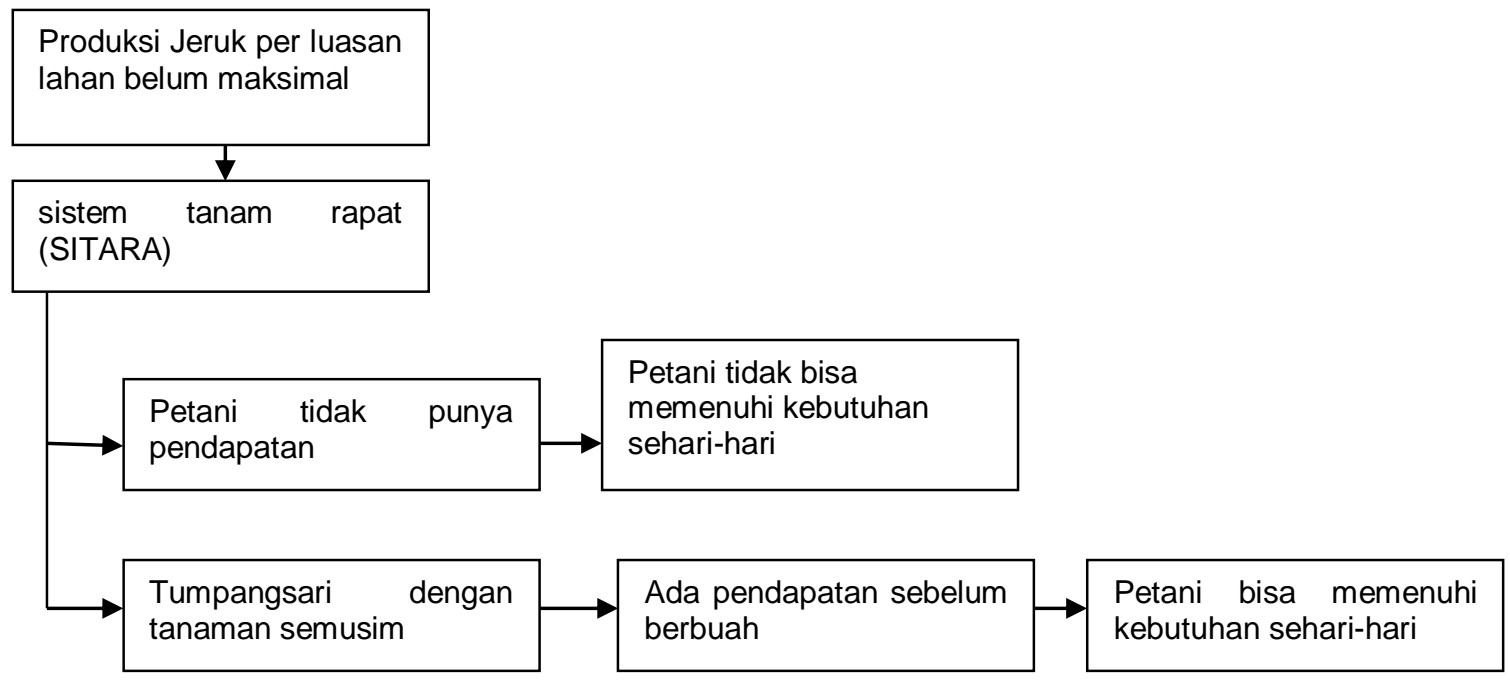

Gambar 3. Alur Permasalahan Produksi Jeruk di Indonesia

\section{Pengumpulan Data}

Penelitian dilakukan di Desa Glagahagung, Kecamatan Purwoharjo dan Desa Bangorejo, Kecamatan Bangorejo, Kabupaten Banyuwangi. Bulan Agustus 2017 dilakukan observasi pertumbuhan tanaman pokok (jeruk) dan tanaman tumpangsari yang telah panen. Pada Bulan Mei 2018 dilanjutkan dengan wawancara ke pengelola demonstrasi plot (demplot). Bulan September 2018 pertumbuhan tanaman pokok (jeruk) kembali diamati.

Teknik pengumpulan data pada penelitian ini menggunakan observasi lapangan yang mana data primer dikumpulkan melalui observasi dan wawancara menggunakan kuesioner terstruktur kepada tujuh petani pengelola demplot budidaya jeruk SITARA yang melakukan budidaya tumpangsari. Di sini dua pola sistem tanam rapat dengan tiga pola 
tumpangsari yang tertuang dalam empat paket dianalisis, yaitu: (1) 4x4 (ganda) dengan tanaman tumpangsari cabai; (2) 4x4 (ganda) variasi semangka, tomat, brokoli, sawi; (3) 3x4 (ganda) dengan cabai; (4) $3 \mathrm{~m}$ x 4 (ganda) kedelai.

\section{Analisis Data}

Analisis yang digunakan dalam penelitian ini adalah analisis usaha tani, yakni penerimaan, biaya, dan keuntungan dari budidaya tumpangsari dengan jangka waktu satu tahun (dari Mei 2017- Mei 2018) dari luasan lahan 0,25 ha. Beberapa perhitungan yang dilakukan untuk menunjang analisis:

(1) Penerimaan usaha tani

$$
\begin{gathered}
T R_{i}=Y_{i} . P y_{i} \\
T R=\sum_{i=1}^{n} Y . P y
\end{gathered}
$$

$\mathrm{TR}=$ total penerimaan $(\mathrm{Rp})$

$\mathrm{i} \quad=$ jenis tanaman tumpangsari

$\mathrm{n} \quad$ = banyaknya jenis tanaman tumpangsari

$\mathrm{Y}=\operatorname{produksi}(\mathrm{kg})$

$\mathrm{P} \quad$ = harga jual (Rp)

(2) Biaya usaha tani (nilai biaya diperoleh dari analisis finansial)

$$
T C=F C+V C
$$

$\mathrm{TC}=$ total biaya $(\mathrm{Rp})$

$\mathrm{FC}=$ biaya tetap $(\mathrm{Rp})$

$\mathrm{VC}=$ biaya variable $(\mathrm{Rp})$

(3) Keuntungan usaha tani

$$
\Pi=T R+T C
$$

$\Pi=$ keuntungan
$\mathrm{TR}=$ Total Penerimaan $(\mathrm{Rp})$

$\mathrm{TC}=$ Total Biaya $(\mathrm{Rp})$

Perhitungan tersebut nantinya diteruskan untuk melihat penerimaan usaha tani menurut luasan usaha, pengalokasian penggunaan input, serta kelayakan usaha. Kelayakan usaha tani dilihat melalui Return Cost Ratio (R/C Ratio) (Shinta 2011), harga pokok produksi dan titik impas. Titik impas adalah titik dimana petani dalam keadaan belum memperoleh keuntungan tetapi juga sudah tidak merugi (Makmur 2016), berikut rumus perhitungan:

$$
\begin{gathered}
\mathrm{R} / \mathrm{CRatio}=T R / T C \\
\mathrm{HPP}=\frac{\text { TotalBiaya }}{\text { VolumeProduksi }} \\
\mathrm{BEP}=\frac{\text { TotalBiaya }}{\text { HargaJual }}
\end{gathered}
$$

Pada paket teknologi yang memberikan profit tertinggi dilakukan analisis sensitivitas jika harga turun sebesar $12 \%$ dan $25 \%$. Hal ini untuk mengetahui kelayakan penerapannya, mengingat sebagian besar tanaman yang diuji cobakan adalah sayuran dan buah, dimana mengalami fluktuasi lebih tinggi dibandingkan tanaman pangan (Irawan 2007). Hasil dilihat dari Benefit Cost Ratio (BCR) yang diperoleh dari perubahan harga. Tingkat suku bunga yang digunakan adalah 4,50\% ketika budidaya tumpangsari dilakukan.

\section{HASIL DAN PEMBAHASAN}

Hasil analisis finansial yang dilakukan menunjukkan bahwa keempat pola tumpangsari yang telah diusahakan dapat 
memberikan keuntungan bagi petani (Tabel 1). Menurut Seran dan Brintha (2010) kelayakan ekonomis budidaya tumpangsari bergantung pada kesesuaian tanaman yang dipilih berikut adaptasi dari pola tanam yang digunakan. Oleh karena itu cabai, kedelai, dan variasi dari semangka-tomat-brokoli-sawi sesuai untuk menjadi tanaman sela jeruk yang belum berproduksi, karena memberikan keuntungan. Pada penelitian sebelumnya tumpangsari kedelai pada jeruk menghasilkan produktivitas jeruk yang tinggi dibandingkan dengan monokultur (Srivastava et al. 2007). Hal ini disebabkan tanaman tumpangsari tersebut Tabel 1. Perbandingan Penerimaan Usaha Tani Berdasarkan Pola Tanam dan Jenis Tumpangsari.

\begin{tabular}{|c|c|c|c|c|c|c|c|c|}
\hline Paket & Pola Tanam & Tumpangsari & $\begin{array}{c}\text { FC } \\
\text { (penyusutan) }\end{array}$ & bi. Saprodi & $\begin{array}{c}\text { bi.tenaga } \\
\text { kerja }\end{array}$ & $\begin{array}{c}\text { TC (Total } \\
\text { Biaya) }\end{array}$ & $\begin{array}{c}\text { TR (Total } \\
\text { Prndapatan) }\end{array}$ & П (Profit) \\
\hline 1 & $4 \times 4 m \quad 625$ & Cabai & 386.667 & 670.000 & 180.000 & 1.236 .667 & 2.155 .000 & 918.333 \\
\hline 2 & $4 \times 4 m \quad 625$ & Variasi & 386.667 & 8.356 .250 & 4.700 .000 & 13.442 .917 & 26.320 .313 & 12.877 .396 \\
\hline 3 & $3 \times 4 \mathrm{~m} 1601$ & Cabai & 386.667 & 302.500 & 62.500 & 751.667 & 2.400 .000 & 1.648 .333 \\
\hline 4 & $3 \times 4 \mathrm{~m} 1601$ & Kedelai & 410.000 & 1.106 .625 & 1.080 .000 & 2.596 .625 & 4.950 .000 & 2.353 .375 \\
\hline
\end{tabular}

Dari Tabel 1. terlihat adanya perbedaan yang cukup signifikan di sisi penerimaan dan profit petani yang menerapkan satu tanaman tumpangsari dengan yang menerapkan variasi, antara 19\%-92\% untuk penerimaan dan $82 \%$ 93\% untuk profit. Penerimaan dan profit paling rendah didapatkan oleh petani yang menerapkan pola tanam SITARA paket 1, yaitu tanaman jeruk dengan jarak $3 \mathrm{~m}$ x $4 \mathrm{~m}$ dengan tumpangsari cabai. Paket yang paling tinggi memberikan profit adalah paket 2, dengan pola tanam $4 \mathrm{~m} \times 4 \mathrm{~m}$ dengan jenis (kedelai) menjadikan ketersediaan hara di dalam tanah menjadi tinggi (Knörzer et al. 2009). Penggunaan sistem tumpangsari pada kebun jeruk yang belum berproduksi juga dapat menjaga keberlangsungan hidup tanaman jeruk itu sendiri karena dapat mengurangi hama penggulung daun (Ahmed et al. 2013). Tanaman cabai dipilih karena harga komoditas ini menjanjikan, sedangkan pemilihan penggunaan variasi/pergiliran tanaman tumpangsari dilakukan untuk mengantisipasi jika harga salah satu komoditas jatuh.

tanaman tumpangsari variasi (semangkatomat-brokoli-sawi).

Pengalokasikan biaya yang menjadi input produksi pada Tabel 1 berbanding lurus dengan penerimaan dan profit, meskipun pengecualian terjadi pada paket 3 . Hal ini menjadi indikasi bahwa apa yang diinvestasikan ke lahan akan kembali dalam bentuk produksi atau pun produktivitas yang akhirnya menaikkan penerimaan dan profit (Nainggolan \& Tarigan 2013; Alitawan \& Sutrisna 2017). Komposisi biaya rata-rata pada budidaya tumpangsari masih didominasi oleh biaya variabel sebesar 91\%, yang meliputi 
sarana produksi (saprodi) terdiri dari benih, pupuk, dan penanganan hama penyakit (fungisida $\&$ herbisida) berikut tenaga kerja (Gambar 4).

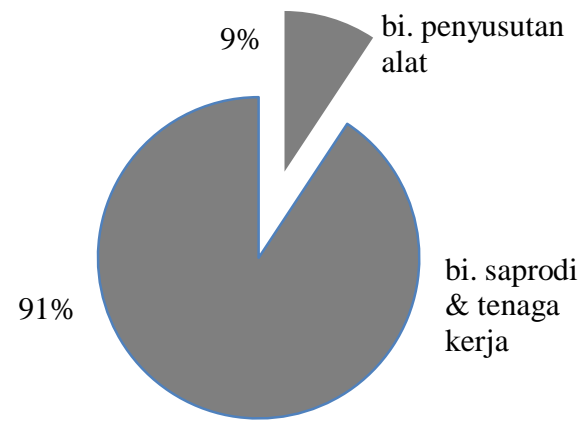

- Rata-rata TFC Rata-rata TVC

Gambar 4. Komposisi Biaya Rata-rata (FC dan VC) dari Pola Tanam dan Jenis Tumpangsari.

Dalam penelitian ini terlihat lebih jelas, bahwa biaya variabel yang dikeluarkan lebih difokuskan kepada biaya saprodi sebesar 55\%, sedangkan biaya tenaga kerja rata-rata hanya sebesar 35\% (Gambar 5). Alokasi paling tinggi dari biaya saprodi adalah untuk pestisida dan fungisida sebesar 49\%, sedangkan paling rendah untuk lain-lain (pengairan) sebesar 2\% (Gambar 6). Hal ini menunjukkan kebergantungan produk hortikultura akan pestisida dan fungisida masih tinggi. Di sisi lain alokasi biaya pupuk yang berdasarkan laporan Febrianti \& Dewi 2018 menempati $78 \%$ dari saprodi, tidak terjadi di tumpangsari pada budidaya jeruk sitara. Berkaitan dengan hal tersebut perlu diteliti lebih dalam interaksi pohon (dalam hal ini jeruk),tanah, dan tanaman semusim (Hairiah et al. 2000).
Empat puluh empat persen dari biaya tenaga kerja (Gambar 5) dialokasikan untuk pengolahan lahan, sedangkan pengalokasian paling kecil pada pemeliharaan, sebesar $2 \%$. Berbeda dengan laporan Febrianti \& Dewi 2018 yang menempatkan panen sebagai penyerap biaya tenaga kerja yang paling tinggi. Di sini, biaya tenaga kerja sebagian besar berasal dari dalam keluarga yang belum sepenuhnya dihargai, hal ini sejalan dengan laporan Kuheba et al. 2016 dan Mufidah et al. 2018. Oleh karena itu perlu memahamkan ke petani pentingnya menghitung tenaga rill yang dibutuhkan.

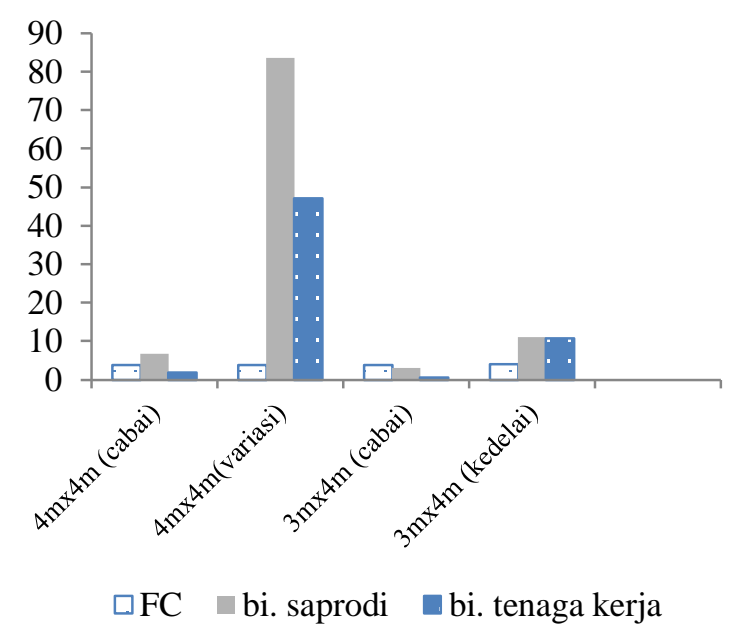

Gambar 5. Komposisi Biaya Tetap, Saprodi dan Tenaga Kerja dari Pola Tanam dan Jenis Tumpangsari 


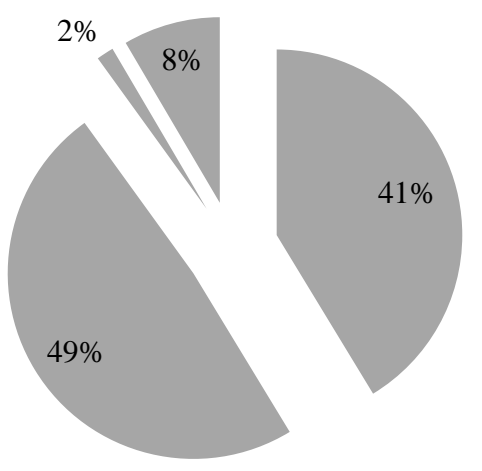

$\begin{array}{ll}\square \text { pupuk } & \square \text { pestisida+fungisida } \\ \square \text { lain-lain } & \square \text { benih }\end{array}$

Gambar 6. Komposisi Alokasi Biaya Saprodi dari Keempat Paket.

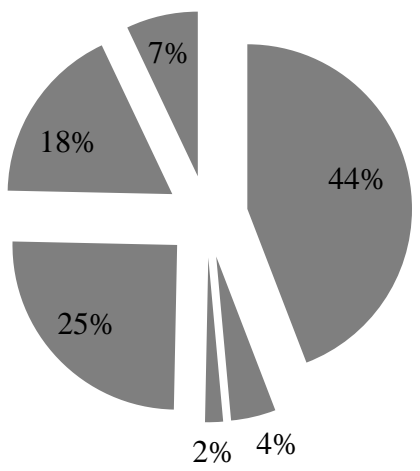

$\begin{array}{ll}\square \text { Pengolahan lahan } & \text { Penanaman } \\ \square \text { Pemeliharaan } & \text { Pemupukan } \\ \square \text { Pengendalian hama } & \quad \text { Lain-lain (panen) }\end{array}$

Gambar 7. Komposisi Alokasi Biaya Tenaga Kerja dari Keempat Paket.
Pada Tabel 2. terlihat bahwa penerimaan cabai rendah, bukan dikarenakan harga jual yang lebih rendah dari komoditas lain, justru cabai menempati posisi tertinggi. Penerimaan rendah lebih dikarenakan karena budidaya cabai yang dilakukan di sela budidaya jeruk SITARA terkena air, sehingga menyebabkan busuk, dan sebagian hasil panen tidak dapat dijual. Pola penanaman SITARA pagar ganda yang terlihat pada Gambar 2. pada penerapannya di Banyuwangi, bagian tengah merupakan tempat aliran air untuk irigasi.

Harga pokok produksi tertinggi kedua setelah cabai adalah kedelai, hal ini dapat menjadi indikasi dicarinya kedelai lokal di pasaran. Di sini ada hal menarik yang dapat dilihat yaitu meskipun $\mathrm{R} / \mathrm{C}$ rasio jenis tanaman yang bervariasi masih lebih rendah daripada pola tanam $3 \mathrm{~m} \times 4 \mathrm{~m}$ dengan kedelai, namun dengan adanya rotasi dapat menghindari jatuhnya harga, sehingga harga komoditas yang tinggi dapat menutupi harga komoditas yang rendah.

Tabel 2. Analisis R/C Rasio, HPP dan BEP Budidaya Jeruk di SITARA (dalam 0,25 ha dari Mei 2017-Mei 2018).

\begin{tabular}{|c|c|c|c|c|c|c|c|c|}
\hline No & Pola Tanam & Tumpangsari & $\begin{array}{l}\mathrm{R} / \mathrm{C} \\
\text { rasio }\end{array}$ & $\begin{array}{c}\text { TC } \\
\text { (Biaya Total) }\end{array}$ & $\begin{array}{l}\text { Volume } \\
\text { produksi }\end{array}$ & $\begin{array}{c}\text { Harga } \\
\text { penjualan } \\
(\mathrm{Rp})\end{array}$ & $\begin{array}{c}\text { HPP } \\
(\mathrm{Rp} / \mathrm{kg})\end{array}$ & $\begin{array}{l}\text { BEP } \\
(\mathrm{kg})\end{array}$ \\
\hline 1 & $4 \times 4 m \quad 625$ & Cabai & 1,74 & 1.236 .667 & 175 & 12.300 & 7.067 & 101 \\
\hline \multirow[t]{5}{*}{2} & $4 \times 4 m \quad 625$ & Variasi & 1,96 & 13.442 .917 & & & & \\
\hline & & semangka & & 2.521 .667 & 4.500 & 1.100 & 560 & 2.292 \\
\hline & & tomat & & 5.627 .917 & 5.000 & 3.264 & 1.126 & 1.724 \\
\hline & & brokoli & & 3.771 .667 & 3.000 & 1.250 & 1.257 & 3.017 \\
\hline & & sawi & & 1.521 .667 & 2.000 batang & 625 & 761 & 2.435 \\
\hline 3 & $3 \times 4 m \quad 1601$ & Cabai & 3,19 & 751.667 & 160 & 15.000 & 4.698 & 50 \\
\hline 4 & $3 \times 4 m \quad 1601$ & Kedelai & 1,91 & 2.596 .625 & 412,75 & 8.000 & 6.291 & 325 \\
\hline
\end{tabular}


Dengan demikian, profit yang didapatkan lebih besar. Dari hasil analisis sensitivitas akan paket 2 (Tabel 3) terlihat bahwa budidaya tumpangsari semangka-tomat-brokoli-sawi masih layak dilakukan, dengan nilai BCR lebih dari 1, meskipun harga masing-masing komoditas mengalami penurunan sebesar $12 \%$ dan $25 \%$.

Tabel 3. Analisis Sensitivitas Usaha Tani Tumpangsari (Paket 2) di Banyuwangi, pada Perubahan Harga $12 \%$ dan $25 \%$.

\begin{tabular}{lrr}
\hline \multicolumn{1}{c}{ Kondisi } & \multicolumn{1}{c}{ NPV } & $\begin{array}{c}\text { BCR } \\
\text { (Rasio Biaya } \\
\text { Manfaat) }\end{array}$ \\
\hline Awal & 12.322 .867 & 1,96 \\
Harga komoditas & 9.258 .070 & 1,72 \\
turun 12\% & & \\
$\begin{array}{l}\text { Harga komoditas } \\
\text { turun 25\% }\end{array}$ & 5.990 .032 & 1,47 \\
\hline
\end{tabular}

\section{KESIMPULAN}

$\mathrm{cm}, 43 \mathrm{~cm}$, dan $228 \mathrm{~cm}$. Hal ini dapat menjadi indikasi bahwa tumpangsari dapat dilakukan dengan tidak merugikan tanaman pokok, jika mendapat perlakuan yang sesuai. Studi lebih lanjut terkait kondisi tanah dan dampak jangka panjang tumpangsari terhadap pertumbuhan tanaman yang belum menghasilkan dapat dilakukan untuk memperkuat usaha tani yang dilakukan.

\section{UCAPAN TERIMA KASIH}

Ucapan terima kasih penulis sampaikan kepada Balai Penelitian Tanaman Jeruk dan Buah Subtropika (Balitjestro) selaku instansi yang memberikan dana dan fasilitas untuk melaksanakan kegiatan penelitian ini, serta
Tanaman tumpangsari dari empat paket perlakuan layak untuk diusahakan, merujuk nilai R/C rasio yang bernilai lebih dari satu. Pola tumpangsari paket 2 variasi (semangkatomat-brokoli dan sawi) yang ditanam pada jeruk SITARA dengan jarak $4 \mathrm{~m}$ x $4 \mathrm{~m}$ memberikan penerimaan dan profit paling besar. Hasil dari analisis sensitivitas juga menunjukkan ketika terjadi penurunan harga sebesar $12 \%$ hingga $25 \%$ dari masing-masing komoditas, semangka-tomat-brokoli-sawi, budidaya tanaman ini masih layak untuk diusahakan, meskipun penerimaan yang didapatkan mengalami penurunan. Pola ini ternyata juga memberikan pertumbuhan tanaman jeruk yang lebih baik daripada keempat pola lainnya, terlihat dari indikator diameter batang bawah, batang atas dan tinggi tanaman rata-rata yang lebih tinggi, yaitu 52

kepada tim Teknologi Budidaya Jeruk Sistem Tanam Rapat (SITARA) tahun 2017-2018 di Balitjestro atas kerjasama yang baik selama proses penelitian berlangsung. Penulis juga mengucapkan terima kasih kepada teknisi Agus yang membantu observasi dan pengumpulan data di lapangan. Ucapan terima kasih juga penulis sampaikan kepada petani jeruk SITARA di Banyuwangi yang bersedia untuk meluangkan waktunya dan memberikan informasi. Tidak lupa juga, ucapan terima kasih yang tak terhingga ditujukan kepada Pusbindiklat LIPI yang telah memberi kesempatan pada penulis untuk mengikuti Diklat Jabatan Fungsional Peneliti Tingkat I. Penulis juga mengucapkan banyak 
terima kasih kepada Prof . Dr. Dewa Ketut Sadra

Swastika, M.S. yang telah menginspirasi serta

sabar dalam memberikan masukan dan koreksi dalam penulisan karya tulis ilmiah ini di tengah jadwalnya yang padat.

\section{DAFTAR PUSTAKA}

Ahmed, S., M.A. Khan, and M. Qasam. 2013. Effect of Intercropping of Maize in Citrus Orchards on Citrus Leaf Miner Infestation and Population of Its Natural Enemies. Pak J Agri Sci. 50: 91-93.

Alitawan, A.A., dan K. Sutrisna. 2017. Faktorfaktor yang Mempengaruhi Pendapatan Petani Jeruk pada Desa Gunung Bau Kecamatan Kintamani Kabupaten Bangli. E-Jurnal EP Unud. 6: 796-826.

Aubert, B. 1990. High Density Planting (HDP) of Jiaogan Mandarine in the Lowland area of Shantou (Guangdong China) and Implications for Greening Control. In: Proc 4th Int Asia Pacific Conf Citrus Rehabil. Chiang Mai, Thailand; p. 149157.

BPS. 2017. Konsumsi Buah Dan Sayur Susenas Maret 2016. Jakarta.

BPS. 2018. Ekspor dan Impor. Jakarta.

Daniel, M. 2002. Pengantar Ekonomi Pertanian. Bumi Aksara, Jakarta.

Febrianti, T., dan M. Dewi. 2018. Komparasi Pendapatan Usahatani Tanaman Hortikultura di UPT Bulupountu Jaya Kabupaten Sigi Sulawesi Tengah. In: Peran Keanekaragaman Hayati untuk Mendukung Indonesia sebagai Lumbung Pangan Dunia. Vol. 2. Surakarta; p. 9299.

Ford, S., R. Muraro, G. Fairchild. 1989. Economic Comparison of Southern and Northern Citrus Production in Florida. Proc. Fla. State. Hort Soc J. 02: 27-32.

Guo, Z., Y. Zhang, P. Deegen, H. Uibrig. 2006. Economic Analyses of Rubber and Tea Plantations and Rubber-Tea Intercropping in Hainan, China. Agrofor Syst. 66: 117-127.

Hairiah, K., D. Suprayogo, M. van Noordwijk. 2000. Interaksi Antara Pohon - Tanah -
Tanaman Semusim : Kunci Keberhasilan Atau Kegagalan. In: Bahan Ajar 2 Int Cent Res Agrofor (ICRAF) Bogor. Bogor; p. 1-23.

Irawan, B. 2007. Fluktuasi Harga, Transmisi Harga, dan Marjin Pemasaran Sayuran dan Buah. Anal Kebijak Pertan [Internet]. 5:358-373. Available from: http://www.ejurnal.litbang.pertanian.go.i d/index.php/akp/article/view/4667/3949

Knörzer, H., S. Graeff-hönninger, B. Guo, P, Wang. 2009. Climate Change, Intercropping, Pest Controll and Beneficial Microorganisms [Internet]. Netherlands: Springer Netherlands. Available from: http://link.springer.com/10.1007/978-90481-2716-0

Kuheba, J.A., J.N. Dumais, P.A. Pangemanan. 2016. Perbandingan Pendapatan Usahatani Campuran Berdasarkan Pengelompokan Jenis Tanaman. J AgriSosioekonomi Unsrat. 12: 77-90.

Makmur. 2016. Analisis Biaya Produksi dan Titik Impas Usaha Kecil Pembuatan Sari Jahe Instan. J Ilm Cano Ekon. 5: 55-62.

Mufidah, L., L. Zamzami, S. Wuryantini. 2018. Analisa Usaha Tani Jeruk Siam di Lahan Kering (Konawe Selatan) dan Lahan Pasang Surut ( Batola ). In: Peran Keanekaragaman Hayati untuk Mendukung Indonesia sebagai Lumbung Pangan Dunia. Vol. 2. Surakarta; p. 1117.

Mursidah. 2007. Analisis Komparatif Usahatani Tumpangsari Karet-Pisang Kepok dan Karet-Nenas. J. Eko Pert Pemb. 4(2): 37-42.

Nainggolan, I., S. Tarigan. 2013. Analisis Usahatani Jeruk dan Faktor-faktor yang Mempengaruhi Penerimaan Petani. J Soc Econ Agric Agribus. 2: 1-15.

Nchanji, Y.K., R.N. Nkongho, W.A. Mala, P. Levang. 2016. Efficacy of Oil Palm Intercropping by Smallholders: Case study in South-West Cameroon. Agrofor Syst. 90: 509-519.

Pusat Data dan Sistem Informasi Pertanian. 2013. Analisis PDB Sektor Pertanian Tahun 2013. Jakarta.

Rehman, A., R. Qamar, J. Qamar. 2014. Economic Assessment of Sugarcane 
(Saccharum officinarum L.) through Intercropping. J Agric Chem Environ. 3: 24-28.

Seran, T., and I. Brintha. 2010. Review on Maize Based Intercropping. J Agron. 9: 135-145.

Shinta, A. 2011. Ilmu Usahatani. Universitas Brawijaya Press, Malang.

Soekartawi. 1995. Analisis Usahatani. UI Press, Jakarta.

Srivastava, A.K., A.D. Huchche, L. Ram, S. Singh. 2007. Yield Prediction in Intercropped versus Monocropped Citrus Orchards. Sci Hortic. 114: 67-70.

Stuchi, E., and E. Girardi. 2010. Use of Horticultural Practices in Citriculture to Survive Huanglongbing. In: Proc Second intenational Res Conf Huanglongbing. Orlando: University of Florida; p. 189190.

Tachibana, S., S. Nakai. 1989. Relationships between Crown Density, Yield and Leaf Area Index in Different Planting Densities in Wase Satsuma Mandarins (Citrus unshiu Marc. var. Praecox Tanaka). J Japanese Soc Hortic Sci. 58: 91-96.

Yaseen, M., M. Ahmad. 2010. Nutrition Management in Citrus: Effect of Multinutrients Foliar Feeding on the Yield of Kinnow at Different Locations. Pakistan J Bot. 42: 1863-1870. 